\title{
Representation of two Contrary States of Human Soul: Songs of Innocence and Experience by William Blake
}

\author{
Dr. Suprita Jha
}

\author{
Associate Professor, Department of English, Mata Sundri College, University of Delhi, India
}

Received: 11 Oct 2020; Received in revised form: 30 Nov 2020; Accepted: 19 Dec 2020; Available online: 31 Dec 2020 (C)2020 The Author(s). Published by The Shillonga Publication. This is an open access article under the CC BY license (https://creativecommons.org/licenses/by/4.0/).

\begin{abstract}
It is difficult to ignore the basic point about William Blake that though chronologically he is an eighteenth-century poet, he is a highly gifted and immensely successful lyric poet. While Blake's poetry may or may not have the pleasantness of great poetry, it is perhaps true that Blake has no notable predecessors and no followers. He consistently stresses the importance of freedom, as opposed to the tyranny that he feels to be characteristic of the government of his day, and attacks negative moralizing, which he associates with the church, as opposed to a true sense of religion. The Songs of Innocence and of Experience occupy a vital place in the corpus of Blake's poetical writings. This is so because these Songs are as much the product of Blake's earlier writings as the pointer to his future writings. The kind of philosophical tone that we encounter in The Songs of Innocence and of Experience is indeed astounding. It is said that Blake looked upon poetry as something that is dictated by spirits, or as the result of inspiration, but he was also aware of the role of the poet to bring out certain truths of human life in front of the people in a symbolic way. There is no doubt about the fact that in the corpus of English Poetry no other poet has got as much success, if equal but certainly not more, as Blake. The present paper is mainly focused on the philosophical appeal and symbolic portrayal of human existence that the Songs of William Blake illustrate to us.
\end{abstract}

Keywords-Innocence, Experience, Purity, Introduction, Human Soul, Love, Cruelty, Guilt, Misery, Lamb, Tiger.

\section{INTRODUCTION}

It must be pointed out at the very outset that 'Romanticism' is a thoroughly controversial term, and to define it is a very difficult task. According to Walter Pater, 'romanticism means the addition of strangeness to beauty whereas classicism is order in beauty'. Herford points out that the Romantic Movement was primarily 'an extraordinary development of imaginative sensibility'. Whatever be the interpretation of the term 'romanticism', it is clear that it was essentially a reaction to the nature or natural power. In England the Romantic Movement implies a reaction against the school of Dryden, Pope and Dr. Johnson. The Romantic Movement was thus a revolt against literary tradition. But it was more; it was also a revolt against social authority. The romantic poets can often be seen glorifying the simplicity of the style and necessity of the action in their works.

William Blake was an engraver who also pursued the careers of poet and painter. For a while, he was part of a radical group of thinkers and writers. In the early phase of his poetic career, as we can see, from the first collection of his poems called The Poetical Sketches, Blake did write verses in imitation of various poets such as Shakespeare, the Elizabethan song-writers, Spenser, Milton, Gray and Collins. Blake did so perhaps to learn the trade of poetry. Thereafter, however, what he writes is unmistakably his own, and we do never find him looking back. It is said that Blake looked upon poetry as something that is dictated by Spirits, or as the result of inspiration, but he was also aware of the role that the conscious mind must play in the process of poetic creation. The manuscripts of Blake's Songs show that the poet would revise certain key words and phrases repeatedly like morality, super power, god etc. His best known works are the Songs of Innocence, published in 1789 and then, in 1794, the Songs of Experience were added. They are apparently the collection of simple poems and they deal with two contrary states of human soul: the state of Innocence, in which the world is unthreatening, there are no moral restrictions, and God is trusted implicitly; and the state of Experience, which reflects a fallen world of repression and religious hypocrisy. 


\section{EXPOSITION}

As we go through The Songs of Innocence, what we get in them is a child's vision of the world, a world of purity, of joy, of security. Here the poet sees a vision of a child on a cloud who instructs him first to play a tune, then sing and then write his poems down. It is the very first poem of these Songs entitled "Introduction" that sets their tone. It symbolizes the conventional eighteenth- century pastoral terms by the shepherd's pipe. Blake is very much present as the narrator of this poem. We have absolutely no difficulty in realizing that, in Blake's view, all children, whether white or black, are pure, and that is why they are compared with the Lamb whose 'innocent call' is heard all through these songs. The narrator asks us to relate the lamb's image as the most innocent of God's creatures to the image of his maker, the 'Lamb of God'. It is indeed useful to remember that in these poems both the child and the Lamb serve as the symbol for Christ. It is indeed unmistakable that in the Songs of Innocence, the spirit of joy, of 'sweet joy', is conveyed by the sun, by the ringing of bells, by the voices of birds and by the rejoicings of Nature itself. However, there is hardly a poem in these Songs in which the symbol of protection or security, a guardian-figure of some kind, does not occur. It is in this connection that we may refer to such symbols as those of the mother, the nurse, the shepherd, the lion, the angels and above all, God Himself that figure in 'The Echoing Green', 'The Shepherd', The Cradle Song', 'The Nurse's Song' and 'A Dream'. Nevertheless, we have to keep this constantly in mind that The Songs of Innocence are not only the songs about the children or for children and that they do not deal just with 'sweet dreams of pleasant streams'. The truth is that despite their apparent simplicity, there is something extremely meaningful and profound about them.

As we move on to The Songs of Experience we find ourselves in a different kind of world and atmosphere. It is a world, not of purity, joy or security, but of guilt, misery and tyranny and naturally the prevailing mood is one of disillusionment. The benign guardians are there no more, and their place has been taken by the tyrants. Urizen is Blake's symbol for the arch-tyrant, and his agents- the Kings, the priests and the parents- are the symbol of cruel authority on this earth. Urizen stands for unreason and traditional religion, and his dark shadow broods over most of these Songs. He hates life and joy; he is jealousy and cruelty, and is none other than the Jehovah of the Old Testament. It is only natural that the images that Blake employs in The Songs of Experience communicate bondage and a callous hostility to life. The introductory poem sets the scene for the fallen world that Blake portrays through Songs of Experience. The 'Holy Word' is not really the voice of God; but it is a voice of a false creator who wants man's soul to be satisfied with 'The starry floor, The watery shore', which are mere distractions from the real life of imagination. In 'Earth's Answer' earth's vital energies are frozen; 'the sick Rose' has been attacked by 'the invisible worm', and it is eternal winter there with darkness and the howling storm threatening the very reality of existence. Similarly, in these Songs the earth is fettered by jealousy; the School Boy is imprisoned like a bird in a cage, and we hear of the 'mind-forged manacles'. The important symbols that we encounter in The Songs of Experience are those of the Sun-flower, the Poisoned Tree, the Sick Rose, the Dismal Tree of Mystery, the Ancient Bard and the Tiger. Though Blake speaks of Urizen, he maintains that all the qualities that he represents are within us, and, according to the poet, it is for this reason that we find ourselves to be the victims of fear, intolerance, jealousy and cruelty. Urizen is a false god; the true God, says Blake, is the God of Love that Christ personifies. In Blake's opinion, this God of Love too does not dwell apart from us; He is within us. In The Marriage of Heaven and Hell Blake says:' God only acts, and Is, in existing beings or men'.

Blake, no doubt, believes in a close proximity between divinity and humanity, but what is really important is that this God of Love, which is within us, is Blake's Imagination. Imagination may be God's promptings to men; it may be intuition or spiritual sensation, but it certainly liberates and ennobles man. In Blake's prophetic books Los is the symbol of Imagination. In the state of Experience feelings are suppressed and natural impulses are stifled. According to Blake, while expression is good, repression is evil. And it is this very idea that he expresses in two of his poems entitled 'The Voice of the Ancient Bard' and 'The Tiger'. The bard and the Tiger represent the regenerative energy that can break the bond of experience:

Youth of delight, come hither,

And see the opening morn,

Image of truth new-born.

(The Voice of the Ancient Bard)

In his prophetic books the other symbol is Orc which is the symbol of energy. Many of the songs from this part may be seen as visions because Blake does not attempt to draw an explicit lessons; instead he confronts us with two contrasting images and invite us to use our own imagination to draw conclusions.

\section{CONCLUSION}

However, it is clear that the state of Innocence alone is not adequate and that the state of Experience, as it is, is certainly 
not unnecessary. The poet has the intention to show two completely different aspects of human existence and at the same time, he also wants to show the relevance of both the aspects in one's life. William Blake has a unique position among all the romantic poets because he knew about the crude realities of life better than the other romantic poets.

As the ancient Bard points out, an encounter between Innocence and Experience alone can lead to a state of higher Innocence. It is this belief in a dialectical development of human psychology and society that explains Blake's statement: 'there can be no progression without contrarieties'. Blake is a mystical poet, not really because he speaks of anything metaphysical or transcendental, but because he shows his concern for the soul of man, for the outside-inside equation, and in this regard gives us a host of dreams or visions, besides creating his own symbolical network and private mythology. Moreover, Blake is a true romantic poet, not only because he takes us to Nature, to the freedom and joy of human soul, to the primacy of Imagination and Inspiration, or to lyricism, but chiefly because his voice is the voice of a singular individual. And even though Eliot says that Blake's vision was somewhat deficient, he maintains that The songs of Innocence and of Experience are 'the poems of a man with a profound interest in human emotions, and a profound knowledge of them'. Both the books try to imagine life as it might exist outside the conventional habit of thinking, and indeed, see conventional attitudes as the prejudices that destroy and deny human life. This is a typical stance in Romantic literature that the writer detaches his or her self from the received ideas and values. What Blake lamented was the absence of any sense of the spiritual dimension of experience. If we compare Blake's thinking with the kind of ideas encountered at the start of the eighteenth century, we can see that as against a notion of shared values and a shared way of thinking. In the words of T.S.Eliot,' Blake was endowed with a capacity for considerable understanding of human nature, with a remarkable and original sense of language and the music of language, and a gift of hallucinated vision'.

\section{REFERENCES}

[1] Morton D. Paley: William Blake

[2] Andrew Blake: Blakes

[3] Adam Edina: William Blake-Visionary

[4] Andrew Sanders: The short Oxford History of English Literature

[5] John Peck and Martin Coyle: A Brief History of English Literature 